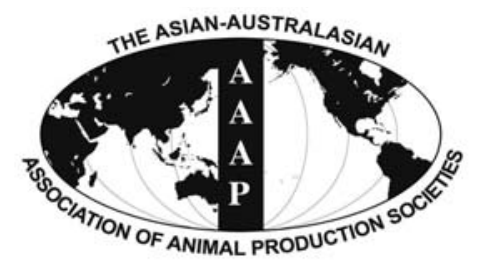

Asian-Aust. J. Anim. Sci.

Vol. 23, No. 1 : 122 - 130

January 2010

www.ajas.info

\title{
The Effects of Excluding Animal Products from the Diet on Sensory Properties of Pork from Pigs Grown in New Zealand as Assessed by Singaporean Panelists
}

\author{
Jasmine Leong ${ }^{1,2,}$ *, Roger W. Purchas ${ }^{1}$, Patrick C. H. Morel ${ }^{1}$ and Brian H. P. Wilkinson ${ }^{1}$ \\ ${ }^{1}$ Massey University, Institute of Food, Nutrition and Human Health, PN 452, \\ Private Bag 11 222, Palmerston North, New Zealand
}

\begin{abstract}
Sensory analyses of pork samples from leg muscles of female pigs raised in New Zealand (n = 17) were conducted using trained and untrained Singaporean panelists. The New Zealand pigs included three dietary groups, with one diet including animal products (NZA), and two containing plant products only (NZP \& NZP+), with the NZP+ diet containing a supplement (0.614\%) containing conjugated linoleic acid (CLA), selenium, and vitamin E. The New Zealand pork was also compared with Indonesian pork as local reference samples $(n=6)$. Pork samples from the NZA group had the highest score for mutton flavour and aftertaste, and the lowest score for brothy aroma, brothy flavour, meaty flavour, lightness and juiciness by trained sensory panels. Samples from NZP and $\mathrm{NZP}+$ were similar except the NZP+ group had a stronger stale flavour than the NZP group (1.34 vs. 0.57 on a 100 -point scale; $<<0.05$ ). The first and second functions of a discriminant analysis based on trained-panel scores for 14 attributes accounted for $95.4 \%$ of the variance, with function 1 (83.7\%) being related mainly to mutton aroma, mutton flavour and aftertaste. Based on a 20-member untrained panel, the NZA pork had the highest mutton aroma and mutton flavour intensities $(\mathrm{p}<0.01)$ and aroma and flavour that was less acceptable than that from the NZP group $(\mathrm{p}<0.05)$. The acceptability scores of Indonesian pork were not significantly different from those of New Zealand pork, but its scores for mutton aroma and mutton flavour were significantly lower than NZP. Overall acceptability was positively associated with acceptability of aroma $(r=0.906)$, juiciness $(r=0.888)$, and tenderness $(r=0.904)$, but negatively associated with intensities of mutton aroma $(r=-0.478)$ and flavour $(r=-0.551)$. (Key Words : Pork Flavour, Discriminant Analysis, Mutton-flavour, Conjugated Linoleic Acid)
\end{abstract}

\section{INTRODUCTION}

Pork is a popular meat consumed by non-muslim Singaporeans with about 87,000 tonnes being consumed per year (Kanagalingam, 2005). Currently, Singapore imports its pork from several countries, but Australian and Indonesian pork is consumed most widely due to its ready availability at supermarkets and wet markets. Fresh pork is obtained from pigs raised in Indonesia but slaughtered at Singapore abattoirs, while chilled pork is mainly imported from Australia and is widely known as "Air Pork". Singaporean consumers are aware of the origin of pork from packaging labels. Results of a recent survey showed

\footnotetext{
* Corresponding Author: Jasmine Leong. Tel: +65-698706164, Fax: +65-67721976, E-mail: JLeongWY@sp.edu.sg

${ }^{2}$ Singapore Polytechnic, School of Chemical and Life Sciences, 500, Dover Road, Singapore 139651.

Received June 17, 2009; Accepted September 12, 2009
}

that Singapore consumers associate non-Indonesian pork with the presence of an unpleasant mutton-like off-flavour (Leong et al., 2008).

One possible cause of off-flavours in pork is by the oxidation of lipids, leading to the formation of aldehydes and short-chain fatty acids (Reindl and Stan, 1982; Devol, et al., 1988). The rate and extent of lipid oxidation depends on a number of factors, the most important being the level of polyunsaturated fatty acids (PUFA) in muscle (Allen and Foegeding, 1981). Pork contains high levels of unsaturated fatty acids relative to ruminant meat (Enser et al., 1996) and is more susceptible to oxidative deterioration of lipids and myoglobin. Feeding of PUFAs to pigs can improve the nutritional quality of pork, but may also increase the susceptibility to oxidation (Sheard et al., 2000; Kouba et al., 2003; Morel et al., 2006). There have been many reports of PUFA-rich feeds leading to increased lipid oxidation and thus off-flavour in pork (Houben and Krol, 1980; Warnants et al., 1998; Roman et al., 1995; Overland et al., 1996; 
Table 2. Definitions of the sensory attributes of cooked pork developed by the trained panelists during training, together with the anchor points at each end of the $150 \mathrm{~mm}$ scale

\begin{tabular}{|c|c|c|}
\hline Sensory attribute & Interpretation & Anchor points \\
\hline \multicolumn{3}{|c|}{ Aroma and odour attributes } \\
\hline Meaty aroma & Aromatics associated with cooked meat ${ }^{1}$ & None/Strong \\
\hline Brothy aroma & Aromatics associated with pork cooked in water ${ }^{1}$ & None/Strong \\
\hline Metallic aroma & Aromatics associated with presence of iron ions ${ }^{1}$ & None/Strong \\
\hline Acidic aroma & Aromatics associated with presence of citric acid² & None/Strong \\
\hline Mutton aroma & Aromatics associated with presence of mutton ${ }^{1}$ & None/Strong \\
\hline Stale odour & A typical aroma generally associated with rancidity of meat and its fat ${ }^{1}$ & None/Strong \\
\hline \multicolumn{3}{|c|}{ Flavour and taste attributes } \\
\hline Meaty flavour & Sensations associated with cooked meat ${ }^{1}$ & None/Strong \\
\hline Brothy flavour & Sensations associated with pork cooked in water ${ }^{1}$ & None/Strong \\
\hline Metallic flavour & Sensations associated with the presence of iron ions ${ }^{1}$ & None/Strong \\
\hline Acidic taste & Taste on the tongue associated with citric acid ${ }^{2}$ & None/Strong \\
\hline Mutton flavour & Sensations associated with cooked mutton ${ }^{1}$ & None/Strong \\
\hline Stale flavour & Atypical taste generally associated with rancidity of meat and its fat ${ }^{1}$ & None/Strong \\
\hline Bitter taste & Taste on the tongue associated with caffeine ${ }^{2}$ & None/Strong \\
\hline Aftertaste & Sensation of lingering taste on the tongue after ingestion ${ }^{1}$ & None/Strong \\
\hline \multicolumn{3}{|l|}{ Other attributes } \\
\hline Brownness & Degree of brownness ${ }^{1}$ & Grey/Brown \\
\hline Lightness & Degree of darkness/lightness ${ }^{1}$ & Light/Dark \\
\hline Juiciness & Sensation of presence of moisture or liquid exudates in the mouth ${ }^{1}$ & None/Strong \\
\hline Tenderness & Ease of breaking down of meat into fine particles when chewed ${ }^{1}$ & None/Strong \\
\hline
\end{tabular}

${ }^{1}$ Definitions as developed by the panelists. ${ }^{2}$ Definitions of Meilgarrd et al. (1999).

water bath at $100^{\circ} \mathrm{C}$ (Memmert brand; model no. W350). The bottles were capped throughout the cooking process to retain aromas and were opened by the panelists during the evaluation. For taste evaluation, $50 \mathrm{~g}$ of minced meat were placed into $150 \mathrm{ml}$ glass jars that were capped and cooked in water $\left(100^{\circ} \mathrm{C}\right)$ for 30 mins. During the cooking process, the minced meat was stirred to prevent clumping together. By opening and closing the jars to do the stirring, much aroma would have been lost, which is why aroma was evaluated separately as described above. Each panelist was provided with an evaluation form, napkins, a covered container for expectoration, water, and plain white bread for cleansing the palate. Each sample was tasted once in each of two sessions with 11 or 12 samples per session to give a total of four sessions. Samples were presented to the panelists randomly and one at a time.

For the untrained panel, each of the 20 untrained panelists (5 males and 15 females, aged between 18 to 45 years) assessed samples from each pig twice for aroma, flavour, juiciness, tenderness and overall acceptability on a scale from 1 to 9 where 1 was "Dislike extremely" and 9 was "Like extremely". They also assessed the intensity of mutton aroma and mutton flavour on a scale where 1 was "None” and 5 was "Intense”. Both panels assessed the pork samples using normal white light at the sensory evaluation booths.
Samples of the semitendinosus muscle were cut into strips (approximately $50 \mathrm{~mm} \times 30 \mathrm{~mm} \times 5 \mathrm{~mm}$ ) and marinated with dark soy sauce (Tai Hua Food Industries Pte Ltd., Singapore; $1 \mathrm{ml}$ of sauce per $2.5 \mathrm{~g}$ of pork) for 10 minutes to impart a dark brownish black colour and a slight salty note to the meat, and then simmered in a covered 3.5 litre slow cooker (Cornell brand: CSJ35) for $30 \mathrm{~min}$ set at $90^{\circ} \mathrm{C}$, $30 \mathrm{~min}$ at $80^{\circ} \mathrm{C}$, and then held at $60^{\circ} \mathrm{C}$ until served. Panelists were served with a tray of four samples (in lidded plastic containers) that they tasted individually on a flour bun (commonly known as 'Mantou'; $80 \times 50 \times 5 \mathrm{~mm}$ ). Three trays of samples were evaluated per session with a total of 46 samples in four sessions over two weeks, so each panelist tasted pork from each pig twice. This method of cooking and presentation was used because it is popular with Singaporeans.

\section{Statistical analysis}

All statistical analyses were carried out using SPSS ver. 17 (SPSS Inc, Singapore). The animals were nested within feed treatment, while treatment and panelist effects were arranged in a factorial manner with samples from every animal being evaluated by every panelist. The data were analysed as a nested-factorial design.

Treatment group effects were tested against animal effects. Both panelist and panelist $\times$ treatment effects were 
tested against panelist×animal (within treatment). Animal within treatment and panelist×animal (within treatment) effects were tested against the overall errors.

Scale marks from QDA were converted to intensity scores from 0 to 100 for each descriptor and analysed by ANOVA (Type I Sums of Squares) at 5\% level of significance using the General Linear Model (GLM) procedures to determine differences among the groups. The Sharpiro-Wilk test for normality of the data indicated that 10 of the 18 attributes in the trained panelist data and two from the untrained panel required some kind of transformation ( $\mathrm{p}<0.05$ for the Shapiro-Wilk's test). Natural logs were used for 12 attributes (acid aroma, metallic aroma, mutton aroma, stale odour, acidic taste, metallic flavour, mutton flavour, stale flavour, bitter taste, and aftertaste for the trained panel, and mutton aroma, and mutton flavour for the untrained panel). Because these 12 attributes included some zero scores, the data were analysed as $\log _{\mathrm{e}}(\mathrm{x}+1)$ where $\mathrm{x}=$ the untransformed value. To get the actual leastsquares means, " 1 " was subtracted from the backtransformed least-squares means. The significance of differences between the least-squares means was assessed using the Least Significant Different test. Relationships between attributes based on animal means were evaluated

Table 3. Least-squares means showing the effects of treatments on sensory attributes of pork as determined by a trained sensory panel

\begin{tabular}{|c|c|c|c|c|c|c|}
\hline \multirow{2}{*}{ Sensory attribute $e^{1,2}$} & \multicolumn{4}{|c|}{ Treatment } & \multirow{2}{*}{ Effects $^{4}$} & \multirow{2}{*}{$\mathrm{R}^{2}(\%), \mathrm{RSD}^{5}$} \\
\hline & NZA & NZP & $\mathrm{NZP}+$ & SG1 & & \\
\hline No. of animals & 6 & 6 & 5 & 6 & & \\
\hline \multicolumn{7}{|c|}{ Aroma and odour attributes: } \\
\hline Meaty aroma & 39.95 & 36.15 & 40.06 & 35.75 & 0.522 & $54.0,23.63$ \\
\hline Brothy aroma & $31.41^{\mathrm{a}}$ & $34.31^{\mathrm{ab}}$ & $41.93^{\mathrm{b}}$ & $37.14^{\mathrm{ab}}$ & 0.025 & $56.2,30.10$ \\
\hline Metallic aroma ${ }^{3}$ & $\begin{array}{c}1.07 \\
(1.92)\end{array}$ & $\begin{array}{c}1.07 \\
(1.92)\end{array}$ & $\begin{array}{c}1.08 \\
(1.94)\end{array}$ & $\begin{array}{c}1.44 \\
(3.22)\end{array}$ & 0.058 & $64.9,1.026$ \\
\hline 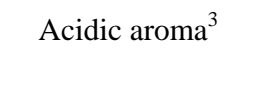 & $\begin{array}{c}0.596^{\mathrm{ab}} \\
\left(0.81^{\mathrm{ab}}\right)\end{array}$ & $\begin{array}{c}0.856^{\mathrm{ab}} \\
\left(1.35^{\mathrm{ab}}\right)\end{array}$ & $\begin{array}{c}0.573^{\mathrm{a}} \\
\left(0.77^{\mathrm{a}}\right)\end{array}$ & $\begin{array}{c}0.922^{b} \\
\left(1.51^{b}\right)\end{array}$ & 0.046 & $71.7,0.742$ \\
\hline Mutton aroma ${ }^{3}$ & $\begin{array}{c}2.38 \\
(9.80)\end{array}$ & $\begin{array}{c}2.29 \\
(8.87)\end{array}$ & $\begin{array}{c}1.86 \\
(5.42)\end{array}$ & $\begin{array}{c}1.95 \\
(6.03)\end{array}$ & 0.108 & $60.2,1.18$ \\
\hline Stale odour ${ }^{3}$ & $\begin{array}{c}0.639 \\
(0.89)\end{array}$ & $\begin{array}{r}0.921 \\
(1.51)\end{array}$ & $\begin{array}{c}0.619 \\
(0.86)\end{array}$ & $\begin{array}{c}0.646 \\
(0.91)\end{array}$ & 0.095 & 73.6, 0.727 \\
\hline \multicolumn{7}{|c|}{ Flavour and taste attributes: } \\
\hline Meaty flavour & $47.66^{\mathrm{a}}$ & $55.53^{\mathrm{b}}$ & $53.13^{\mathrm{b}}$ & $54.72^{\mathrm{b}}$ & 0.002 & $77.8,15.54$ \\
\hline Brothy flavour & $28.51^{\mathrm{a}}$ & $40.91^{\mathrm{b}}$ & $33.15^{\mathrm{ab}}$ & $32.93^{\mathrm{ab}}$ & 0.003 & $83.0,14.64$ \\
\hline Metallic flavour $^{3}$ & $\begin{array}{c}0.929 \\
(1.53)\end{array}$ & $\begin{array}{c}0.755 \\
(1.13)\end{array}$ & $\begin{array}{r}0.947 \\
(1.58)\end{array}$ & $\begin{array}{c}0.674 \\
(0.96)\end{array}$ & 0.382 & $58.9,0.830$ \\
\hline Acidic taste $^{3}$ & $\begin{array}{c}0.629^{\mathrm{ab}} \\
\left(0.88^{\mathrm{ab}}\right)\end{array}$ & $\begin{array}{c}0.499^{\mathrm{ab}} \\
\left(0.65^{\mathrm{ab}}\right)\end{array}$ & $\begin{array}{c}0.860^{\mathrm{b}} \\
\left(1.36^{\mathrm{b}}\right)\end{array}$ & $\begin{array}{c}0.439^{\mathrm{a}} \\
\left(0.55^{\mathrm{a}}\right)\end{array}$ & 0.027 & 71.2. 0.667 \\
\hline Mutton flavour ${ }^{3}$ & $\begin{array}{c}3.42^{\mathrm{c}} \\
\left(29.57^{\mathrm{c}}\right)\end{array}$ & $\begin{array}{c}1.96^{\mathrm{b}} \\
\left(6.10^{\mathrm{b}}\right)\end{array}$ & $\begin{array}{c}2.17^{\mathrm{b}} \\
\left(7.76^{\mathrm{b}}\right)\end{array}$ & $\begin{array}{c}0.897^{\mathrm{a}} \\
\left(1.45^{\mathrm{a}}\right)\end{array}$ & $<0.0001$ & $67.4,1.08$ \\
\hline Stale flavour ${ }^{3}$ & $\begin{array}{c}0.624^{\mathrm{ab}} \\
\left(0.87^{\mathrm{ab}}\right)\end{array}$ & $\begin{array}{c}0.448^{\mathrm{a}} \\
\left(0.57^{\mathrm{a}}\right)\end{array}$ & $\begin{array}{c}0.849^{\mathrm{b}} \\
\left(1.34^{\mathrm{b}}\right)\end{array}$ & $\begin{array}{c}0.343^{\mathrm{a}} \\
\left(0.41^{\mathrm{a}}\right)\end{array}$ & 0.001 & $72.2,0.587$ \\
\hline Bitter taste $^{3}$ & $\begin{array}{c}1.29^{\mathrm{b}} \\
\left(2.63^{\mathrm{b}}\right)\end{array}$ & $\begin{array}{c}1.22^{\mathrm{b}} \\
\left(2.39^{\mathrm{b}}\right)\end{array}$ & $\begin{array}{c}1.37^{\mathrm{b}} \\
\left(2.94^{\mathrm{b}}\right)\end{array}$ & $\begin{array}{c}0.699^{\mathrm{a}} \\
\left(1.01^{\mathrm{a}}\right)\end{array}$ & $<0.0001$ & $79.7,0.683$ \\
\hline Aftertaste $^{3}$ & $\begin{array}{c}3.57^{\mathrm{C}} \\
\left(34.52^{\mathrm{C}}\right)\end{array}$ & $\begin{array}{c}3.10^{\mathrm{b}} \\
\left(21.20^{\mathrm{b}}\right)\end{array}$ & $\begin{array}{c}3.22^{\mathrm{b}} \\
\left(24.03^{\mathrm{b}}\right)\end{array}$ & $\begin{array}{c}2.20^{\mathrm{a}} \\
\left(8.03^{\mathrm{a}}\right)\end{array}$ & $<0.0001$ & $67.2,0.733$ \\
\hline \multicolumn{7}{|l|}{ Other attributes } \\
\hline Colour & 37.89 & 42.56 & 34.58 & 39.07 & 0.353 & $79.3,15.30$ \\
\hline Lightness & 31.30 & 36.13 & 32.01 & 32.15 & 0.707 & $62.1,21.77$ \\
\hline Juiciness & $50.32^{\mathrm{a}}$ & $55.30^{\mathrm{b}}$ & $52.54^{\mathrm{ab}}$ & $52.35^{\mathrm{ab}}$ & 0.031 & $40.0,13.32$ \\
\hline Tenderness & 60.08 & 58.75 & 60.49 & 56.13 & 0.114 & $52.4,14.79$ \\
\hline
\end{tabular}

${ }^{1}$ All attributes were scored on a scale of 0-100 with higher values indicating a stronger note.

${ }^{2}$ Means in the same row with no letters or with a common letter after them do not differ significantly ( $\left.<<0.05\right)$ as determined by Fisher's least significance difference (LSD) mean separation test.

${ }^{3}$ The significance of differences (using LSD) was based on the transformed means ( $\log _{\mathrm{e}}$ ) of these attributes, and the back-transformed means are shown in brackets below the transformed means.

${ }^{4} \mathrm{p}$-values.

${ }^{5}$ Measures of the overall goodness-of-fit for the model include the coefficient of determination ( ${ }^{2}$ (\%)) and the residual standard deviation (RSD). 
Table 4. The largest five coefficients for the first two discriminant functions from the discriminant analysis based on the 14 aroma and taste attributes (Table 1) assessed by the trained panel

\begin{tabular}{lcllc}
\hline \multicolumn{3}{c}{ Discriminant function number } \\
\cline { 1 - 2 } Attribute & Attribute & 2 (11.7\% of variation) \\
\hline Mutton flavour & Discriminant coefficient & & Stale flavour & Discriminant coefficient \\
Meaty aroma & 1.560 & & Meaty aroma & -1.580 \\
Brothy flavour & 1.417 & & Metallic aroma & 1.250 \\
Mutton aroma & -0.936 & & Bitter taste & -1.212 \\
Aftertaste & 0.918 & & Metallic flavour & -1.106 \\
\hline
\end{tabular}

using Pearson's linear correlation coefficients. Discriminant analysis was performed using the scores of 14 aroma and flavour attributes from the trained panel in order to identify combinations of variables that discriminated best among the four treatment groups.

\section{RESULTS}

\section{Trained panel results}

Results in Table 3 indicate that 8 of the 18 attributes were not significantly different among the four groups. Many of the attributes ( 7 out of 14) had very low scores with means less than 4 on the 100-point scale. Brothy aroma scores were significantly higher for the NZP+ than NZA groups, with NZP and SG1 being in-between. Stale odour score was higher for NZP samples than those from NZA, but neither of these differed significantly from the other two groups. Meaty flavour scores were lower for the NZA group than for the other three groups. Brothy flavour was lowest for NZA, which differed significantly from NZP, but not the other two groups. Mutton flavour showed large differences between the groups with NZA having a higher score than NZP or NZP+, and these two groups had higher scores than SG1. The mutton flavour score for NZA was more than 20 times that for SG1. Mean stale flavour score for NZP+ was significantly higher than those for NZP and SG1, but not significantly different from that for NZA. Aftertaste was significantly higher for NZA than SG1 with the other two groups in-between. Juiciness was lower for NZA than SG1. There was a significant positive correlation between acidic and metallic aroma scores $(r=0.659)$, both of which were highest for the NZA group although group differences were not significant. Pork samples from the NZP and NZP+ groups were similar for all attributes except stale flavour, which was higher for NZP+. This similarity was reflected in the closeness of these two groups on the Function-1 scale of the discriminant analysis plot (Figure 1).

The first and second functions of the discriminant analysis (Figure 1) accounted for $95.4 \%$ of the variance, with function 1 being related mainly to mutton aroma,

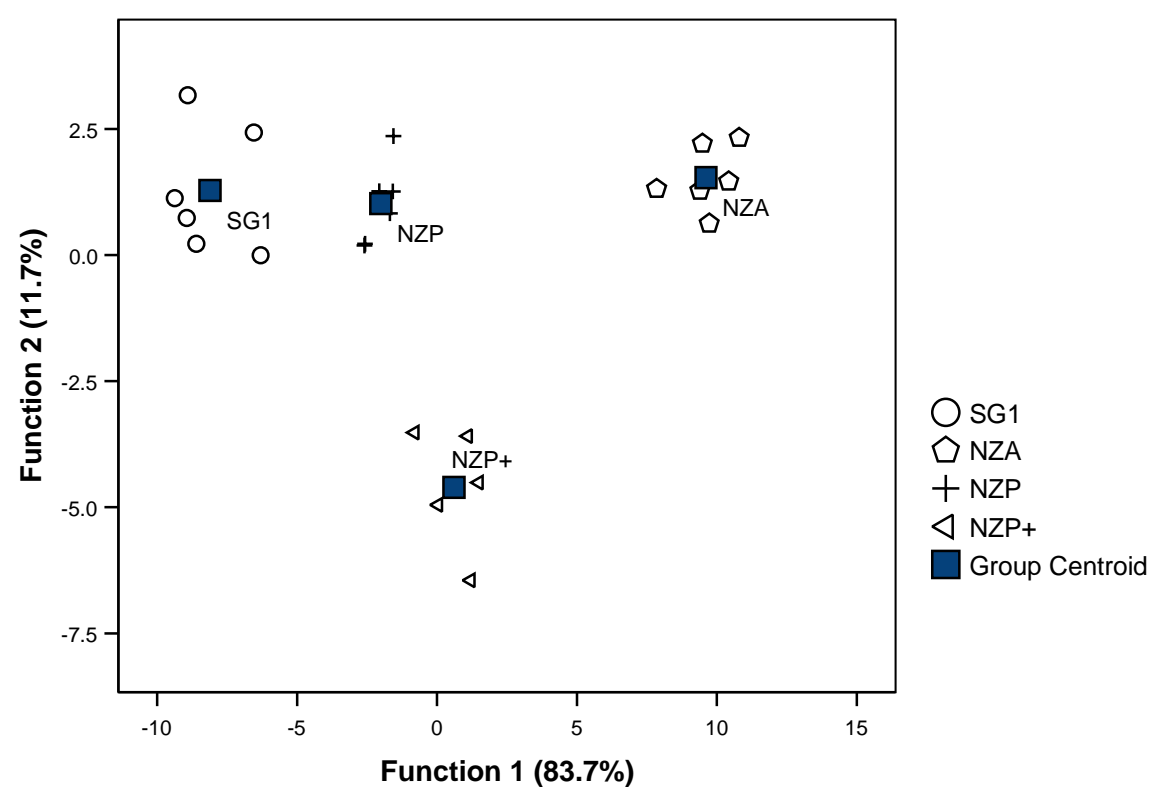

Figure 1. A plot of function 1 versus function 2 from the discriminant analysis based on the 14 aroma and flavour attributes evaluated by the trained panel (Table 1). Points are shown for the 23 individual pigs as well as the treatment group centroids. 
meaty aroma, aftertaste, brothy flavour and mutton flavour, while function 2 reflected mainly meaty aroma, metallic aroma, bitter taste, stale flavour and metallic flavour (Table 4). Function 1 clearly separated the treatments into 3 clusters with little separation of NZP and NZP+, but function 2 clearly separated NZP+ from the other three groups (Figure 1).

Correlations across all 23 samples revealed positive relationships between aftertaste and acidic taste $(r=0.594$; $\mathrm{p}<0.01)$, mutton flavour $(\mathrm{r}=0.884 ; \mathrm{p}<0.01)$, stale flavour $(\mathrm{r}$ $=0.429 ; \mathrm{p}<0.05)$ and bitter taste $(\mathrm{r}=0.444 ; \mathrm{p}<0.01)$. Likewise, mutton flavour was positively related with stale flavour ( $\mathrm{r}=0.361 ; \mathrm{p}<0.05)$, and acidic taste $(\mathrm{r}=0.584$; $\mathrm{p}<0.01)$, but negatively related to meaty flavour $(\mathrm{r}=-0.728$; $\mathrm{p}<0.01)$. Meaty flavour was positively related with brothy flavour $(r=0.72)$.

\section{Untrained panel results}

Results of evaluations by the untrained panel (Table 5) showed no significant differences between the groups for juiciness, tenderness or overall acceptability. Both aroma and flavour of pork from the NZP group was preferred to that from the NZA group, with pork from the SG1 group having an aroma that was of similar acceptability to the NZP group, but a flavour that was significantly less acceptable than for that group. Flavour and aroma acceptability were not different between the NZP and NZP+ groups.

Intensity scores for mutton aroma and flavour from the untrained panel (Table 5) were lowest for pork samples from the SG1 group and highest for the NZA group $(p<0.01)$. Scores for the NZP and NZP+ groups were intermediate. Scores from the untrained panel indicated that higher overall acceptability scores were associated with more acceptable aroma $(r=0.906)$, juiciness $(r=0.888)$, and tenderness $(r=0.904)$, but with lower intensities of mutton aroma $(r=-0.478)$ and flavour $(r=-0.551)$.

\section{DISCUSSION}

\section{Dietary effects on pork flavour}

The relatively low acceptability and high muttonflavour scores for pork from the NZA group may have been due to the higher protein content of the diet for that group (20.6\% vs. $15.2 \%$ for NZP (Morel et al., 2008) and the fact that some of that protein came from meat and bone meal that is likely to have included meat and bone from sheep. The higher protein level would have resulted in more tryptophan being available in the hind-gut (Tuomola et al., 1996; Henry et al., 2002) for microbial degradation to form the flavourful compounds skatole and indole (Lane and Fraser, 1999; Lane et al., 2002). These indolic compounds have also been shown to be implicated in boar taint (Vold, 1970; Walstra and Maarse, 1970). The quantity of tryptophan reaching the hindgut was calculated using the NRC (1998) feedstuff gross tryptophan content and ileal digestibility coefficient. It is estimated that $20 \%$ more tryptophan would have reached the hindgut of NZA pigs relative to NZP pigs ( 0.53 vs. $0.44 \mathrm{~g}$ per $\mathrm{kg}$ of feed, respectively). In addition to the possible extra synthesis of

Table 5. Least-squares means for treatment effects on acceptability and intensity scores as assessed by an untrained panel

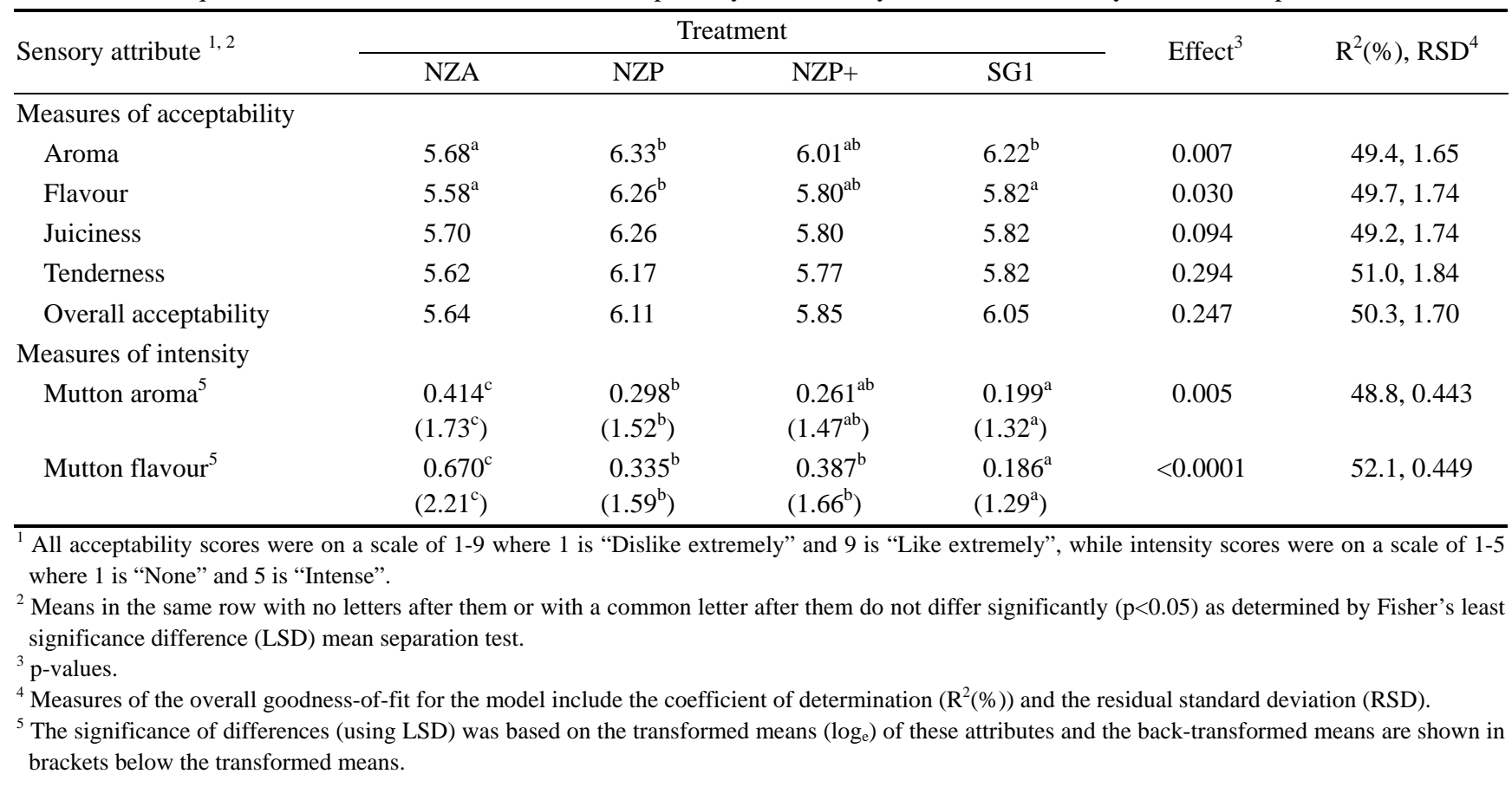


skatole and indole in the hind-gut of pigs in the NZA group, it is also likely that these compounds would have been present in the diet as they are present in sheep meat and fat (Young et al., 1997; Young et al., 2002; Schreurs et al., 2007; Schreurs et al., 2008), and appear to be at least partly responsible for mutton flavour (Hoffman and Meijboom, 1968; Brennand and Linsay, 1982; Young et al., 2003). These flavourful compounds may have been transferred to the pork, as has been reported for fish odours in several studies (Kjos et al., 1999; Lauridsen et al., 1999; Maw et al., 2001; Jaturasitha et al., 2002).

Although not directly comparable because of differences in the cut used, cooking procedures, and the flavour attributes evaluated, it is noteworthy that a trained New Zealand panel did not detect any significant differences between loin samples from the three groups of New Zealand pigs that were assessed in Singapore (Janz et al., 2008) These results suggest that the Singaporean panelists may have been more sensitive to some of the flavour characteristics, possibly due to the low consumption and poor acceptability of sheep meat in many Asian countries (Prescott et al., 2001), including Singapore (Yeo, 1998), which may mean that mutton-like flavours are less acceptable and more apparent than in New Zealand (Pliner, 1982; Crandall, 1985). Prescott et al. (2001) indicated that the low acceptability of sheep meat in Japan was also related to a low level of consumption in that country. In China, consumers describe the hedonically negative cooking odour of sheep meat as soo, meaning sweaty or sour (Wong et al., 1975).

\section{Effects of nutrient supplements on pork flavour}

The supplements of CLA, vitamin E and selenium that were present in the diet of pigs in the NZP+ group did not lead the pork to have significant differences in most of the sensory characteristics assessed by the Singapore panels, or by a New Zealand panel (Janz et al., 2008). The only significant difference $(\mathrm{p}<0.05)$ was a higher stale flavour score for the NZP+ pork relative to the NZP pork, but the mean scores of 1.34 and 0.57 , respectively, on the 100-point scale were very low (Table 3). This result and the assessment by the New Zealand trained panel (Janz et al., 2008) of a slightly more frequent rancid odour for NZP+ compared to NZP, is in agreement with other reports indicating that incorporating CLA into finishing diets of pigs has no appreciable effects on the sensory quality of cooked pork and pork products (Dugan et al., 1999; Wiegand et al., 2002; Corino et al., 2003, Teye et al., 2006). It is unlikely that the duration of feeding the supplement was too short to have an effect as it was fed from weaning to slaughter (Morel et al., 2008), but it may be that the amount of CLA added was not enough to cause an extensive oxidative reaction. Martin et al. (2008) also demonstrated that CLA supplementation at doses lower than $1 \%$ in the diet of pigs did not affect lipid oxidation in loins.

The low levels of stale flavours in NZP+ (1.34) pork as well as NZP (0.57) pork in the current study and that of Janz et al. (2008) may be partly attributable to the antioxidant properties of vitamin $\mathrm{E}$ and selenium that were included in the diet. Vitamin $\mathrm{E}$ can stabilise the membranebound lipids against metmyogloblin $/ \mathrm{H}_{2} \mathrm{O}_{2}$-initiated oxidation (Monahan et al., 1990; Asghar et al., 1991; Monahan et al., 1992).

\section{Comparison of New Zealand and Indonesian pork}

Differences reported here between the locally obtained Indonesian pork and that from New Zealand cannot be interpreted in any depth because there were a number of uncontrolled factors involved. These include the genetic makeup of the pigs, the diet they received, the composition of the pork (Purchas et al., 2009), and the exact nature of the ways in which the pork was treated post mortem. The results indicate, however, that the Singapore panels detected significantly stronger mutton aroma and flavour (untrained panel); and mutton flavour but not aroma (trained panel), in the New Zealand samples, and particularly from pigs that received animal products in their diets (the NZA group).

\section{CONCLUSIONS}

Trained and untrained sensory panels in Singapore were able to detect differences in some flavour and aroma characteristics of pork from pigs raised on different diets in New Zealand with the pork from pigs with some animal products in their diet generally being less acceptable and having a stronger mutton flavour. It is suggested that these differences could be caused by the diet of NZA pigs which contained more protein and possibly some meat and fat from sheep.

The Singapore panels detected differences between pork from the three New Zealand groups that were not detected by a New Zealand panel, but there were some confounding factors in this comparison. These results, however, support previous evidence that sensory results from one population may not necessarily apply for populations in other countries even when trained panelists are involved.

Results showed that dietary supplementation with CLA (conjugated linoleic acid) increased the stale note in pork, but this effect was small, possibly because of the antioxidant effects of the additional vitamin $\mathrm{E}$ and selenium present.

Relative to locally-produced Indonesian pork the pork from New Zealand did not differ significantly in overall acceptability, but did have more intense mutton-like flavour attributes. 


\section{REFERENCES}

Allen, C. E. and E. A. Foegeding. 1981. Some lipid characteristics and interactions in muscle foods-A review. Food Technol. 35: 253-257.

Asghar, A., J. I. Gray, A. M. Booren, E. Gomaa, M. N. Abouzied, E. R. Miller and D. J. Buckley. 1991. Influence of supranutritional dietary vitamin $\mathrm{E}$ levels on subcellular deposition of alpha-tocopherol in the muscle and on pork quality. J. Sci. Food Agric. 57:31-41.

Brennand, C. P. and R. C. Lindsay. 1982. Sensory discrimination of species-related meat flavours. Lebensm-Wissu- Technol. 15:249-252.

Corino, C., S. Magni, G. Pastorelli, R., Rossi and J. Mourot. 2003. Effects of conjugated linoleic acid on meat quality, lipid metabolism, and sensory characteristics of dry-cured hams from heavy pigs. J. Anim. Sci. 81:2219-2229.

Crandall, C. S. 1985. The liking of foods as a result of exposure: eating doughnuts in Alaska. J. Soc. Psychol. 125:187-194.

Devol, D. L., F. K. McKeith, P. J. Bechtel, J. Novakofski, R. D. Shanks and T. R. Carr. 1988. Variation in composition and palatability traits and relationships between muscle characteristics and palatability in a random sample of pork carcasses. J. Anim. Sci. 66:385-395.

Dugan, M. E. R., J. L. Aalhus, A. L. Schaefer and J. K. G. Kramer. 1997. The effect of linoleic conjugated acid on fat to lean repartitioning and feed conversion in pigs. Can. J. Anim. Sci. 77:723-725.

Enser, M., K. Hallett, B. Hewitt, G. A. J. Fursey and J. D. Wood. 1996. Fatty acids content and composition of English beef, lamb and pork at retail. Meat Sci. 42:443-456.

Hoffmann, M. G. and P. W. Meijboom. 1968. Isolation of two isometric 2,6-nonadienals and two isomeric 4-heptanals from beef and mutton tallow. J. Am. Oil Chem. Soc. 45:468-474.

Henry, J., C. J. K. Henry and C. Chapman. 2002. The nutrition handbook for food processors. Woodhead Publishing, England, United Kingdom.

Houben, J. H. and B. Krol. 1980. Acceptability and storage stability of pork products with increased levels of polyunsaturated fatty acids. Meat Sci. 5:57-70.

Janz, J. A. M., P. C. H. Morel, R. W. Purchas, V. K. Corrigan, S. Cumarasamy, B. H. P. Wilkinson and W. H. Hendriks. 2008. The influence of diets supplemented with conjugated linoleic acid, selenium, and vitamin E, with or without animal protein, on the quality of pork from female pigs. J. Anim. Sci. 86:14021409.

Jaturasitha, S., Y. Wudthithumkanaporn, P. Rurksasen and M. Kreuzer. 2002. Enrichment of pork with omega-3 fatty acids by tuna oil supplements: effects on performance as well as sensory, nutritional and processing properties of pork. AsianAust. J. Anim. Sci. 15:1622-1633.

Kanagalingam, U. K. 2005. National standard to ensure safer chilled pork. AVA Vision, pp 5.

Kjos, N. P., A. Skrede and M. Overland. 1999. Effects of dietary fish silage and fish fat on growth performance and sensory quality of growing-finishing pigs. Can. J. Anim. Sci. 79:139147.

Kouba, M., M. Enser, F. M. Whittington, G. R. Nute and J. D.
Wood. 2003. Effect of high-linolenic acid diet on lipogenic enzyme activities, fatty acid composition, and meat quality in the growing pig. J. Anim. Sci. 81:1967-1979.

Lane, G. A. and K. Fraser. 1999. A comparison of phenol and indole flavour compounds in the fat, and of phenols in the urine of cattle fed pasture or grain. NZ. J. Agric. Res. 42:289296.

Lane, G. A., K. Fraser, E. S. Kolver, D. D. Rowan, J. M. Allen, O. E. Mills, A. S. Abraham and S. D. Olney. 2002. Effect of a total mixed ration diet on the concentration of amino acidderived volatiles in milk. Proc. NZ. Soc. Anim. Prod. 62:242245.

Lauridsen, C., G. Anderson, M. Andersson, V. Danielsen, R. Engberg and K. Jakobsen. 1999. Effects of dietary fish oil supplied to pigs from weaning to $60 \mathrm{~kg}$ liveweight on performance, tissue fatty acid composition and palatability of pork when slaughtered at $100 \mathrm{~kg}$ liveweight. J. Anim. Feed Sci. 8:441-456

Leong, J., R. W. Purchas, P. C. H. Morel and B. H. P. Wilkinson. 2008. A survey of the perception of pork by Singapore consumers. Food and Beverage Asia p. 53-56.

Leskanich, C. O., K. R. Matthews, C. C. Warkup, R. C. Noble and M. Hazzledine. 1997. The effect of dietary oil containing (n-3) fatty acids on the fatty acid, physiological, and organoleptic characteristics of pig meat and fat. J. Sci. Food Agric. 75:673683.

Martin, D., T. Antequera, E. Muriel, A. I. Andres and J. Ruiz. 2008. Oxidative changes of fresh loin from pig, caused by dietary linoleic acid and monounsaturated fatty acids, using refrigerated storage. Food Chem. 11:730-737.

Maw, S. J., V. R. Fowler, M. Hamilton and A. M. Petchey. 2001. Effect of husbandry and housing of pigs on the organoleptic properties of bacon. Livest. Prod. Sci. 68:119-130.

Meilgarrd, M., G. V. Civille and B. T. Carr. 1999. Sensory evaluation techniques (third ed.). Boca Raton: FL: CRC Press Inc.

Monahan, F. J., D. J. Buckley, J. I. Gray, P. A. Morrissey, A. Asghar, T. J. Hanrahan and P. B. Lynch. 1990. Effect of dietary vitamin $\mathrm{E}$ on the stability of raw and cooked pork. Meat Sci. 27: 99-108.

Monahan, F. J., D. J. Buckley, P. A. Morrissey, P. B. Lynch and J. I. Gray. 1992. Influence of dietary fat and $\alpha$-tocopherol supplementation in lipid oxidation in pork. Meat Sci. 31:229241.

Morel, P. C. H., J. C. McIntosh and J. A. M. Janz. 2006. Alteration of the fatty acid profile of pork by dietary manipulation. AsianAust. J. Anim. Sci. 19:431-437.

Morel, P. C. H., J. A. M. Janz, R. W. Purchas, W. H. Hendriks and B. H. P. Wilkinson. 2008. The influence of diets supplemented with conjugated linoleic acid, selenium, and vitamin E, with or without animal protein, on the composition of pork form female pigs. J. Anim. Sci. 86:1145-1155.

NRC (National Research Council). 1998. Nutrient Requirements of Swine, 10th revised ed. National Academy Press, Washington, DC.

Overland, M., O. Taugbol, A. Haug and E. Sundstol. 1996. Effect of fish oil on growth performance, carcass characteristics, sensory parameters, and fatty acid composition. Acta Agric. Scand. 46:11-17. 
Pliner, P. 1982. The effects of mere exposure on liking for edible substances. Appetite 3:283-290.

Prescott, J., O. Young and L. O'Neill. 2001. The impact of variations in flavour compounds on meat acceptability: a comparison of Japanese and New Zealand consumers. Food Qual. Pref. 12:257-264.

Purchas, R. W., P. C. H. Morel, J. A. M. Janz and B. H. P. Wilkinson. 2009. Chemical composition characteristics of the longissimus and semimembranosus muscles for pigs from New Zealand and Singapore. Meat Sci. 81:540-548.

Reindl, B. and H. J. Stan. 1982. Determination of volatile aldehydes in meat as 2, 4-dinitrophenyhydrazones using reversed-phase high performance liquid chromatography. J. Agric. Food Chem. 30:849-854.

Romans, J. R., D. M. Wulf, R. C. Johnson, G. W. Libal and W. J. Costello. 1995. Effects of ground flaxseed in swine diets on pig performance and on physical and sensory characteristics of $\omega-3$ fatty acid content of pork. II. Duration of $15 \%$ dietary flaxseed. J. Anim. Sci. 73:1987-1999.

Schreurs, N. M., W. C. McNabb, M. H. Tavendale, G. A. Lane, T. N. Barry, T. Cummings, K. Fraser, N. Lopez-Villalobos and C. A. Ramırez-Restrepo. 2007. Skatole and indole concentration and the odour of fat from lambs that had grazed perennial ryegrass/white clover pasture or Lotus corniculatus. Anim. Feed Sci. Technol. 138:254-271.

Schreurs, N. M., G. A. Lane, M. H. Tavendale, T. N. Barry and W. C. McNabb. 2008. Pastoral flavour in meat products from ruminants fed fresh forages and its amelioration by forage condensed tannins. Anim. Feed Sci. Technol. 146:193-221.

Sheard, P. R., M. Enser, J. D. Wood, G. R. Nute, B. P. Gill and R. I. Richardson. 2000. Shelf life and quality of pork and pork products with raised $n-3$ PUFA. Meat Sci. 55:213-221.

Stone, H. and J. L. Sidel. 1998. Quantitative descriptive analysis: developments, applications, and the future. Food Technol. 52:48-52.
Teye, G. A., P. R. Sheard, F. M. Whittington, G. R. Nute, A. Stewart and J. D. Wood. 2006. Influence of dietary oils and protein level on pork quality. 1. Effects on muscle fatty acid composition, carcass, meat and eating quality. Meat Sci. 73:157-165.

Tuomola, M., M. Vahva and H. Kallio. 1996. High performance liquid chromatography determination of skatole and indole levels in pig serum, subcutaneous fat, and submaxillary salivary glands. J. Agric. Food Chem. 44:1265-1270.

Vold, E. 1970. Report No 238, Institute of Animal Genetics and Breeding, NLH, Volebekk, Norway.

Walstra, P. and H. Maarse. 1970. IVO-Rapport No. 2. Researchgroep Vlees en Vleeswaren TNO, Zeist.

Warnants, N. J., M. Van Oeckel and C. V. Boucque. 1998. Effects of incorporation of dietary polyunsaturated fatty acids in pork backfat on the quality of salami. Meat Sci. 49:435-445.

Wiegand, B. R., J. C. Sparks, F. C. Parrish Jr. and D. R. Zimmerman. 2002. Duration of feeding conjugated linoleic acid influences gorwth performances, carcass traits and meat quality of finishing barrows. J. Anim. Sci. 80:637-643.

Wong, E., C. B. Johnson and L. N. Nixon. 1975. The contribution of 4-methyloctanoic (hircinoic) acid to mutton and goat meat flavour. NZ. J. Agric. Res. 18:261-266.

Wood, J. D., R. I. Richardson, G. R. Nute, A. V. Fisher, M. M. Campo, E. Kasapidou, P. R. Sheard and M. Enser. 2003. Effects of fatty acids on meat quality: a review. Meat Sci. 66:21-32.

Yeo, P. K. 1998. Trends in food composition. Statistics Singapore Newletter, Singapore Department of Statistics.

Young, O. A., J. L. Berdague, C. Viallon, S. Rousset-Akrim and M. Theriez. 1997. Fat-borne volatiles and sheepmeat odour. Meat Sci. 45:169-181.

Young, O. A., G. A. Lane, A. Priola and K. Fraser. 2003. Pastoral and species flavour in lambs raised on pasture, lucerne or maize. J. Sci. Food Agric. 83:93-104. 